\title{
MONITORING OF SAWFLY POPULATIONS (Hymenoptera, Symphyta: Hoplocampa spp.) IN PLUM AND APPLE ORCHARDS USING VISUAL TRAPS
}

\author{
Rimantas Tamosiunas, Laisvune Duchovskiene, and Alma Valiuskaite \\ Lithuanian Research Centre for Agriculture and Forestry, Institute of Horticulture, Babtai, Kaunas District, 30 Kauno Str., LT-54333 \\ r.tamosiunas@Isdi.It
}

Communicated by Viesturs Melecis

The investigation of Hoplocampa minuta (Christ, 1791) (black plum sawfly), Hoplocampa flava (Linné, 1760) (yellow plum sawfly) and Hoplocampa testudinea (Klug, 1816) (apple sawfly) populations using white sticky traps Rebel ${ }^{\circledR}$ bianco was carried out in conventionally and organically managed apple and conventionally managed plum orchards of the Institute of Horticulture of Lithuanian Research Centre for Agriculture and Forestry in 2010 and 2011. Temperature sums for predicting sawfly spring emergence were determined: $120 \pm 5$ degree-days for apple sawfly, $85 \pm$ 26 degree-days for black plum sawfly and $95 \pm 28$ degree-days for yellow plum sawfly. However, more years of the study are needed to confirm these temperature sums. The average densities of sawflies during the flight period were: $\mathrm{H}$. minuta $-14.8 \pm 7.3$ sawfly trap ${ }^{-1}$ in 2010 and $54.2 \pm$

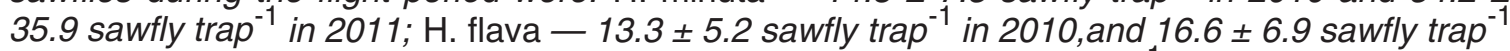
in 2011; and $\mathrm{H}$. testudinea in organic orchard $-38.3 \pm 26.2$ sawfly trap ${ }^{-1}$ in 2010 and $5.0 \pm 2.8$ sawfly trap ${ }^{-1}$ in 2011 , in conventional orchard $-14.8 \pm 8.1$ sawfly trap ${ }^{-1}$ in 2010 and $9.3 \pm 4.3$ sawfly trap ${ }^{-1}$ in 2011. Conditions for development of both plum sawfly species were better in 2011, when abundance nearly reached the economic threshold. Population density, cumulative trap catches during the flight period, and damage caused by apple sawfly varied significantly between the study years and apple cultivars. In 2010, apple sawfly was more abundant and caused more serious damage than in 2011. The economic threshold of 30-40 individuals per trap was reached in 2010 due to the better conditions of development. The various apple cultivars suffered different damage levels: cv. 'Aldas', 'Vitos' and 'Rubinola' suffered the highest damage in the organic orchard, but no significant differences were observed. In the conventional garden, cv. 'Auksis' had the most damaged fruits.

Key words: Hoplocampa testudinea, H. minuta, H. flava, white sticky traps, orchard pest monitoring.

\section{INTRODUCTION}

Apple sawfly (Hoplocampa testudinea) is a common and widespread pest of commercial apple orchards in Europe and North America, often causing severe yield losses and strongly reducing production value (Miller et al., 1956; Nagy, 1959; Nagy, 1960; Alford, 1984). Damage caused by apple sawfly has been repeatedly reported from the United Kingdom and all parts of continental Europe (Velbinger, 1939; Заянчкаускас, 1979; Lukaš and Kocourek, 1998; Ciglar and Barić, 2002; Achtberg, 2004; Taeger et al., 2006; Roller and Haris, 2008, Walzak et al., 2009). Black (H. minuta) and yellow (H. flava) plum sawflies are major pests in plum orchards, frequently causing heavy damage and yield losses in commercial and organic orchards (Wildbolz and Staub, 1986; Caruso and Cera, 2004). The ability of one sawfly larva to penetrate two to four apple or plum fruitlets provides the destructive potential of these pests. In years when fruit load is low or apple sawfly infestation is high, economic losses often exceed that caused by codling moth (Cydia pomonella L.), one of the key pests in apple orchards worldwide (Graf et al., 1996a). In Lithuania, as well as in the neighbouring countries, apple and plum sawfly control strategies are based mainly on pesticide treatment - mostly synthetic pyrethroids with a contact mode of action. Treatments are usually applied before and immediately after the flowering period, combining them with other insecticides against other common apple pests (Raudonis et al., 2007). It has been demonstrated in a number of studies that most of the common insecticides are effective against apple and plum sawflies and thus, the crucial factor of successful control of apple sawfly populations is the timing of application (Wildbolz and Staub, 1986; Höhn et. al, 1993; Ciglar and Barić, 2002). So far, no integrated pest manage- 
ment (IPM) tactics have been applied to control apple and plum sawflies in Lithuania. Visual and pheromone traps, temperature driven models, weather monitoring, and prediction of pest activities and economic effects are tools of IPM to decide on the type, dosage and timing on applied insecticides to reduce the number of treatments (MacHardy, 2000).

The aim of this study was to determine the temperature sum (TS) for apple and plum sawfly spring emergence based on soil temperature at $10 \mathrm{~cm}$ depth and to determine the relationship between trap catches and infestation levels in Lithuanian conditions.

\section{MATERIALS AND METHODS}

The field study was conducted at the experimental apple and plum orchards of the Institute of Horticulture (Lithuanian Research Centre for Agriculture and Forestry) in Central Lithuania (E55 ${ }^{\circ} 4$; N23 ${ }^{\circ} 48^{\prime}$ ) in two consecutive seasons from 2010 to 2011. Apple sawfly populations were investigated in conventionally and organically cultivated apple orchards located ca. $0.7 \mathrm{~km}$ from each other. They were productive, 6-8 year old orchards in 2010. Rows were oriented in the south-north direction and planting distances were $4 \times 2 \mathrm{~m}$ (density 1250 trees $^{-1} \mathrm{a}^{-1}$ ). The conventionally managed orchard had size 13 ha, in which different apple cultivars were planted in two-row blocks. Insecticide (deltamethrin, beta-cyfluthrin) treatments were applied during the pink bud stage (BBCH 58-59); no treatments were applied during petal fall. In the organic orchard (0.5 ha), apple cultivars were arranged in random order throughout the orchard in four repetitions per cultivar; each repetition plot consisted of four trees. The organic orchard was maintained in accordance with all rules of organic gardening, including lack of any pesticide and artificial fertiliser since planting. Apple cultivars of regional economic importance for commercial and organic horticulture were selected for the survey. Cultivars surveyed, rootstock, cultivars sampled, number of traps deployed and number of fruitlets sampled during the study period are presented in Table 1 . All varieties were moderately-late to late blooming. Plum sawfly populations were surveyed in a plum orchard located approximately $0.8 \mathrm{~km}$ from the organic apple orchard. Most trees in the orchard were plum hybrids planted in four-tree plots and arranged in random order. The investigation was conducted on cv. 'Stanley' planted in three rows and positioned near the edge of the orchard. Rows were oriented in the NE-SW direction. Pruning, shaping and care of plum cv. 'Stanley' were conducted as recommended, the grass between rows was repeatedly mown and fungicides against main diseases were applied during the period of the study.

White sticky traps Rebell ${ }^{\circledR}$ bianco (Andermatt Biocontrol, Switzerland) were used to monitor sawfly flight activity and population density. In the first year of the study, 17 traps were set up in the conventional and four traps in the organic plum orchards. Traps were arranged equally throughout the area of the conventional orchard in the following way. In
THE EXPERIMENTAL DESIGN OF THE STUDY

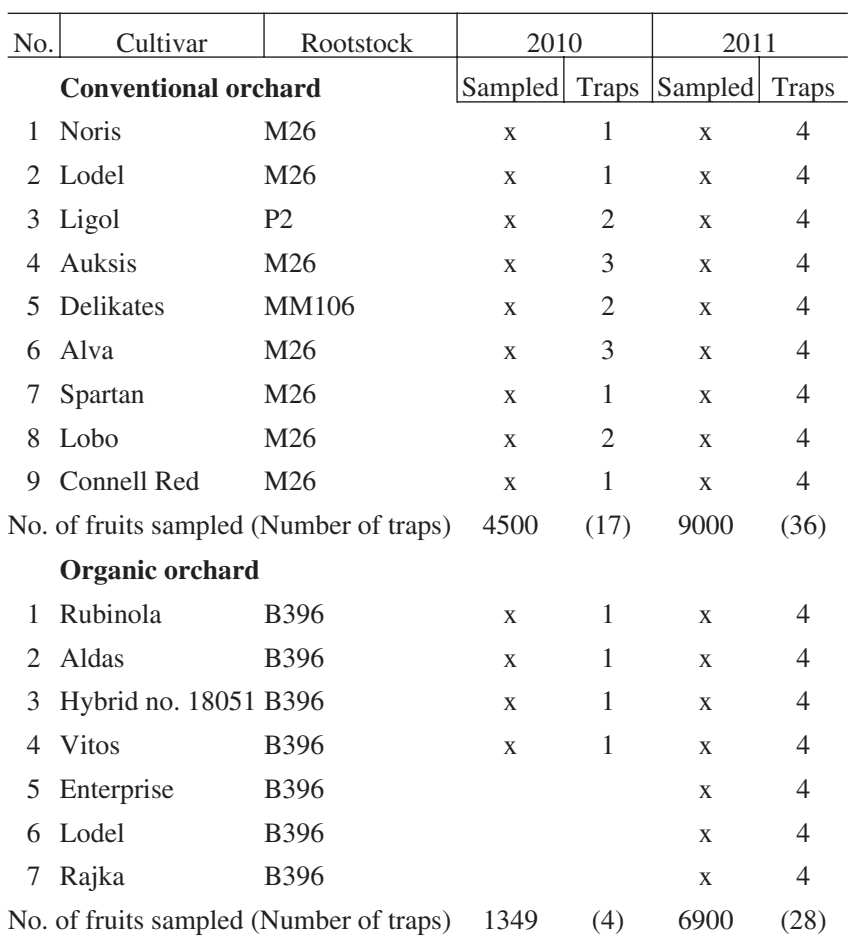

the plum orchard four traps were arranged within three rows. In 2011, the arrangement of traps was modified to four traps per each cv. in both orchards and three varieties were added to the survey in the organic orchard. In the plum orchard, one trap was added. In the conventional orchard, study plots consisted of two neighbouring rows per variety equipped with four traps, of which two were placed closer towards the end and two towards the centre of the rows at 30-50 m distances. In the organic orchard, traps were set up in each of four plots per variety and distances between traps varied between 5-10 m. Overall, 36 and 28 traps were established in conventional and organic orchards and five traps in the plum orchard. Traps were hung on branches or supporting wires at height $1.6-1.7 \mathrm{~m}$ on the external southern part of the tree canopy.

In every year of the survey, the white sticky traps were placed in the orchards two weeks before the beginning of May. In order to determine the beginning of adult sawfly flight period, traps were inspected every two days. After catching the first sawflies, traps were checked once per week in 2010 and in every 2-3 days in 2011. Sawfly imagoes were counted and removed from the traps, then sexed ex situ in the laboratory by using a microscope. Traps heavily filled with other insects were replaced once per sampling period in order to retain effective capture.

On-tree fruit injury surveys were performed before fruitdrop by visual examination. Hundred (or 50 if fruit setting was low) fruits per tree were selected randomly from lower, central and upper parts of the tree canopy for damage assessment (500 fruits per cultivar in 2010 and 1000 fruits in 2011) (Coli et al., 1985; Graf et al., 1996b). 
Daily temperatures were recorded in soil at $10 \mathrm{~cm}$ depth and $150 \mathrm{~cm}$ above ground by an iMetos ${ }^{\circledR}$ weather station (Pessl Instruments, Austria) located at the experimental apple orchard of the LRCAF Institute of Horticulture, ca. 0.5-1.5 $\mathrm{km}$ from the experimental sites. In a previous study, a model used to determine beginning of wasp flight in relation to temperature sum (Zijp and Blommers 1997): a temperature sum of 134 degree days calculated from 1April was found to be the most appropriate estimate of first sawfly emergence. Therefore, we used this method. Effective temperature sums were calculated using the sinusoid between daily minimum and maximum temperatures (Rabbinge 1976). A thermal threshold of $4{ }^{\circ} \mathrm{C}$ was used in the calculation and two dates for starting of calculation were used: first day when the thermal threshold was reached and 1 April.

Trap catch data (population density) in different apple cultivars and total sum of trap catches between two years independently of cultivar per orchard were compared by a nonparametric Mann-Whitney test, as trap catch data was not normally distributed and had a negative binomial distribution. Variety-dependent differences between the infestation levels were compared using a Kruskal-Wallis test. Infestation levels were expressed as percentages and calculated using the formula $\mathrm{A} / \mathrm{B} * 100$, where $\mathrm{A}$ - infested fruit number on a cultivar, $\mathrm{B}$ - overall fruit number sampled on a cultivar. Statistical analysis was performed only between cultivars in which at least three traps were used. Sawfly density data were expressed as mean values per trap with standard deviations. The relationships between trap catches and infestation levels, and between main flowering season and, main flight period of sawfly per cultivar, were tested by means of non-parametric Spearman ranked correlation analysis (Zar, 2010), Analysis was performed separately for all orchards since trap densities were different. All statistical tests were performed using the statistical software Sigmaplot.

\section{RESULTS}

Apple sawfly adult spring emergence, population parameters and crop damage. In both years of the investigation, the first imagoes appeared at a sum of $120 \pm 5$ degreedays (dd) in the organic orchard and $129 \pm 8$ dd in the conventional orchard. In the organic orchard, the first sawflies were observed on 4 May (day 124) in 2010 and on 2 May (day 122) in 2011. In the conventional orchard, there was a four-day (18 dd) delay of sawfly emergence compared to the organic orchard in 2011 and between 2010 and 2011, the date of earliest spring emergence also differed by two days (4 May in 2010 and 6 May in 2011). The overall sawfly flight period was 27-29 days in the organic and 25-27 days in the conventional orchard in both years of the study. The peak $25 \%$ of the flight period corresponded to $160 \pm 2$ dd in the organic and $283 \pm 2$ dd in the conventional orchard, $50 \%$ of the cumulative flight period corresponded to $216 \pm 8 \mathrm{dd}$ and $317 \pm 2 \mathrm{dd}$ and $75 \%$ of the cumulative flight period coincided with $259 \pm 11$ dd and $335 \pm 9$ degree-days in both orchards. Temperature sum accumulation at the be- ginning of flight did not differ significantly $(P>0.05)$ between orchards. However, there were significant differences between sawfly activity patterns at $25 \%, 50 \%$ and $75 \%$ of cumulative flight in both orchards $(P<0.001, P<0.005$ and $P<0.005$, respectively). In 2010, sawfly adult emergence coincided with the beginning of the flowering period of the bulk of cultivars in both orchards. However, in 2011, adults started to appear more than a week before the beginning of the flowering period. During both years of the study, the most active sawfly period (from $25 \%$ to $75 \%$ of cumulative flight) in the organic orchard coincided with the main flowering phase (BBCH 62-67) of all surveyed cultivars, although in 2010 , this period was slightly shifted towards the ending of the flowering period. In contrast, the peak density period of apple sawfly in the conventional orchard had a notable shift towards the end of flowering phase of each cultivar, in 2010 coinciding with $\mathrm{BBCH}$ 66-68 and in 2011 it started right after the end of petal fall. Correlation analysis showed a significant strong relationship between main flowering season and main flight period of sawfly per cultivar in both orchards $(\mathrm{r}=0.742, P<0.001$ for the conventional orchard; $r=0.876, P<0.001$ for the organic orchard).

The density of sawfly populations varied between study years and different management systems (Fig. 1). In the first year of the study, the mean overall density of sawflies during the adult flight period reached $38.3 \pm 26.2$ and $14.8 \pm$ 8.1 sawfly trap ${ }^{-1}$ in organic and conventional orchards. In 2011, overall population density was lower in both orchards $-5.0 \pm 2.8$ sawfly trap ${ }^{-1}$ in organic and $9.3 \pm 6.9$ sawfly trap ${ }^{-1}$ in conventional orchards. However, different trap density in the management systems did not allow comparison of population densities. Sawfly density and extent of damage to apple fruits also varied between different apple cultivars. The overall trap catches and infestation levels are presented in Table 1. Infestation levels between cultivars where at least three traps were set up were compared. In the organic orchard no comparison was possible using the 2010 data and no significant differences between culti-

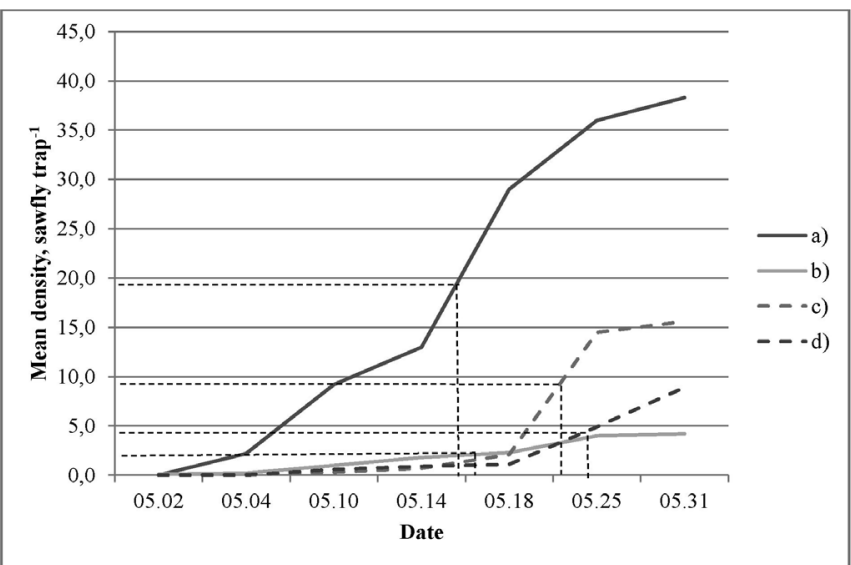

Fig. 1. Cumulative apple sawfly density in different study years and different management systems: a) organic orchard, 2010; b) organic orchard 2011; c) conventional orchard 2010; d) conventional orchard 2011. Dotted lines point $50 \%$ of cumulative density. 
vars were detected in 2011 (Kruskal-Wallis, $P>0.05$ ). In the conventional orchard, a significantly higher infestation level was observed only on one apple cultivar - Auksis in 2010 (Kruskal-Wallis, $P<0.05$ ). In 2011, due to extremely low damage levels, no significant differences between cultivars were observed. A negative relationships between trap catch and infestation level was detected in the conventional orchard in 2011, but due to an extremely low infestation level, the significance of this relationship is unlikely. No other significant correlation was obtained in all three years of the study in organic orchard.

Plum sawfly adult spring emergence, population parameters and crop damage. The spring emergence of both plum sawfly species differed between the two years of the study and also slightly between the species. In 2010, first specimens of black plum sawfly appeared on traps on May 1 and the first yellow plum sawflies on 3 May. In 2011, spring emergence of both species was earlier than in 2010 and was recorded on 26 April for black and 27 April for yellow plum sawflies. The following temperature sums for spring emergence of plum sawflies were determined: $85 \pm$ 26 for $H$. minuta and $95 \pm 28$ for $H$. flava. In both years of the investigation, the flight period started well before the flowering period of cv. 'Stanley' and coincided with $\mathrm{BBCH}$ 56 and BBCH 51 in 2010 and 2011. The greatest flight activity of both species coincided with the ending stage of the flowering period (BBCH 65-67) in 2010 and with the main flowering stage (BBCH 59-69) in 2011. Population density of both species varied between the two years: in 2010, the overall cumulative density did not differ significantly $(P>$ $0.05)$ between species, with black plum sawfly being slightly more abundant $\left(14.8 \pm 7.3\right.$ sawfly trap $\left.^{-1}\right)$ compared to that of the yellow sawfly $\left(13.3 \pm 5.2\right.$ sawfly trap $\left.^{-1}\right)$. In 2011 , overall cumulative density of black sawfly was higher $\left(54.2 \pm 35.9\right.$ sawfly trap $\left.^{-1}\right)$ than that of yellow sawfly (16.6 \pm 6.9 sawfly trap $\left.^{-1}\right)$, but the difference was not significant $(P>0.05)$. Infestation level of both species varied between years: $7.0 \%$ of damaged fruit in 2010 and $27.8 \%$ in 2011 . Cumulative mean density of both species combined and extent of damage are presented in Table 2.

\section{DISCUSSION}

Emergence and flight activity of apple and plum sawflies depend on soil and air temperature. A study by Zijp and Blommers (1997) demonstrated that the most appropriate date to start TS calculation is based on soil temperature recorded at $5 \mathrm{~cm}$ depth starting on April 1. Using this method the mean TS of apple sawfly was 134 degree-days with very low standard deviation of only 8 degree-days over eight years. A number of studies have shown that overwintering apple sawfly larvae break diapause before the lower developmental threshold is reached, and thus post-diapause development can begin as soon as the temperature reaches the threshold value (Zijp and Blommers, 1993; Graf et al., 1996b). In Lithuania, the date soil temperatures reach $4{ }^{\circ} \mathrm{C}$ can differ significantly from 1 April. Therefore, a fixed starting date was not considered to be best suited for TS ac-

\section{Table 2}

APPLE SAWFLY CUMULATIVE MEAN DENSITY AND INFESTATION LEVELS ON DIFFERENT APPLE CULTIVARS AND PLUM CV. STANLEY

\begin{tabular}{|c|c|c|c|c|}
\hline \multirow[b]{2}{*}{ Cultivar } & \multicolumn{2}{|c|}{2010} & \multicolumn{2}{|c|}{2011} \\
\hline & $\begin{array}{c}\text { Infested fruit } \\
\%\end{array}$ & \begin{tabular}{|c|}
$\begin{array}{c}\text { Cumulative } \\
\text { mean density, } \\
\text { sawfly trap }^{-1}\end{array}$ \\
\end{tabular} & $\begin{array}{c}\text { Infested fruit } \\
\%\end{array}$ & $\begin{array}{l}\text { Cumulative } \\
\text { mean density, } \\
\text { sawfly trap }^{-1}\end{array}$ \\
\hline \multicolumn{5}{|c|}{ Conventional orchard } \\
\hline Noris & $18.2 *$ & $11.0 *$ & 0.1 & 7.5 \\
\hline Lodel & $3.4^{*}$ & $7.7 *$ & 0.1 & 6.8 \\
\hline Ligol & 0.0 & 12.0 & 0.0 & 15.5 \\
\hline Auksis & 14.2 & 33.3 & 0.2 & 4.0 \\
\hline Delikate & 1.8 & 9.0 & 0.2 & 5.8 \\
\hline Alva & 0.6 & 12.0 & 0.0 & 16.8 \\
\hline Spartan & $2.6^{*}$ & $11.0^{*}$ & 0.0 & 7.8 \\
\hline Lobo & $8.8^{*}$ & $22.0 *$ & 0.0 & 8.8 \\
\hline Connell Red & $1.0^{*}$ & $15.0^{*}$ & 0.0 & 11.0 \\
\hline Total & 5.6 & 14.8 & 0.1 & 9.3 \\
\hline \multicolumn{5}{|c|}{ Organic orchard } \\
\hline Rubinola & $13.3 *$ & $17.0^{*}$ & 0.5 & 3.0 \\
\hline Aldas & $24.3 *$ & $16.0 *$ & 1.7 & 1.3 \\
\hline 18051 & $11.9 *$ & $51.0^{*}$ & 2.5 & 5.5 \\
\hline Vitos & $14.7 *$ & $69.0 *$ & 1.7 & 8.3 \\
\hline Enterprise & & & 1.8 & 3.5 \\
\hline Lodel & & & 3.2 & 4.8 \\
\hline Rajka & & & 2.2 & 8.7 \\
\hline Total & 16.2 & 38.3 & 1.9 & 5.0 \\
\hline \multicolumn{5}{|c|}{ Plum orchard } \\
\hline Stanley & 7.0 & 14.0 & 35.4 & 25.0 \\
\hline
\end{tabular}

cumulation. We decided to use the threshold of $4^{\circ} \mathrm{C}$ as the starting point for accumulated TS calculation. Choice of thermal threshold as a starting point for TS calculation can be more practical than a fixed starting date, as it would be more reliable when used for different localities. In our study, a temperature sum of $120 \pm 8$ degree-days was required. Soil temperatures were recorded at $10-\mathrm{cm}$ depth, where temperatures tend to be lower and respond slower to air temperature changes and solar insulation than at a $5-\mathrm{cm}$ depth. This is why a smaller TS was obtained in the study by Zijp and Blommers (1997). The choice to measure soil temperature at $10 \mathrm{~cm}$ appears to be more realistic, since sawflies have been shown to occur in 5-30 cm depth depending on soil type. It should be mentioned that two years is period too short to determine a reliable temperature sum for practical use, but we still consider our findings as a contribution to the establishment of this relationship and as useful for apple sawfly forecasting until more reliable temperature sums will be established. More years of study are needed to confirm these temperature sums. Sawfly population density influences the extent of fruit damage. The level of damage depends also on coincidence of peak sawfly density with the susceptible flowering phase (Chaboussou, 1961). In our study, density and infestation levels varied be- 
tween years, but no direct relation between trap catches and infestation levels was found. In 2010, in both apple orchards, highest sawfly density coincided with full bloom of the majority of cultivars, and therefore, resulted in high fruit damage. In the conventional orchard, highest numbers of sawfly adults were observed at the end of apple bloom. This resulted in less damage than in the organic orchard where peak density of the apple sawfly population reached its maximum in the time of full bloom of the orchards. In 2010, the apple bloom period was prolonged and the later emerged adults had a chance to oviposit successfully. Furthermore, of the significant correlation between main flowering season and main flight period of sawfly per cultivar can explain the infestation level. Differences in timing of flight periods and blooming phases of orchards in different years helped us to demonstrate the importance of coincidence between highest sawfly density and susceptible phenological phase of apple and plum trees. According to Wildbolz and Staub (1984) the damage threshold of apple sawfly is 30-40 sawfly trap ${ }^{-1}$ and that of plum sawflies is 80-100 sawfly $\operatorname{trap}^{-1}$ for both species. In another study, a damage threshold of 30-40 sawfly trap ${ }^{-1}$ for apple cultivar 'Idared' was specified for Eastern Swiss conditions, which corresponded to $4.5 \%$ primary sawfly damage, but only $2 \%$ for cv. 'Golden Delicious', although less than half the number of sawflies was caught (Graf et al., 1996b) than in other studies. This suggests that varietal differences in risk assessment of the apple sawfly should be taken into account. Furthermore, in order to achieve reliable sawfly risk assessment, at least three traps per variety per year should be used and traps should be installed at the same distances. In our study, high infestation levels were reached even when trap catches were less than the established threshold. Of course, higher density of traps in the organic orchard may affect estimation of population density and therefore comparison between the studies might be biased. Additionally, higher density of traps in the organic orchard may have resulted in higher infestation levels at lower population densities than in the conventional orchard. Unfortunately, we did not observe a direct relationship between trap catches and damage levels. In the present study, infestation levels varied between cultivars in different orchards. In the organic orchard, the level of damaged fruit was high and varied between cultivars over two years, but no significant differences were observed. However, in the conventional orchard, cultivar 'Auksis' suffered significantly more damage than other surveyed cultivars. This indicates higher apple sawfly risk for this apple cultivar. However, when plum sawfly density was significantly lower than the defined economic threshold, the extent of damage was still high, especially in 2011. This suggests that both plum sawfly species can cause severe damage even at lower densities if conditions are favourable and if the peak flight period coincides with flowering phase of particular cultivar.

Short conclusions of the study: density of the sawfly population had some effect on the infestation level. Nevertheless, other major significant factors were involved, one of them being coincidence between peak sawfly flight period and flowering stage of host plant. Although the established economic thresholds were not exceeded, damage to certain cultivars was high, but no direct relation was observed between trap catches and infestation. The apple cultivar 'Auksis' was found to be susceptible to apple sawfly attack and in management practices should be observed more carefully in localities where apple sawfly problems are frequent. Further study is needed to determine varietal differences. A contribution to the establishment of temperature sums to predict apple and plum sawfly adult spring emergence was made. These temperature sums can be used in practice but with caution due to limited amount of years of observation. Further studies are needed to confirm these temperature sums. Growers or advisory services that utilise soil temperature monitoring could use these temperature sums for more accurate timing of trap installation in different geographical localities.

\section{ACKNOWLEDGEMENTS}

The present research was supported by the long-term research programme "Harmful organisms in agro and forest ecosystems (KOMAS)" implemented by Lithuanian Research Centre for Agriculture and Forestry.

\section{REFERENCES}

Alford, D. V. (1984). A Colour Atlas of Fruit Pests, Their Recognition, Biology and Control. London: Wolfe Publishing Ltd. 320 pp.

Achterberg, C., van (2004). Hymenoptera. Fauna Europaea version 1.1, http://www.faunaeur.org.

Caruso, S., Cera, M. C. (2004). Control strategies for Plum Sawflies (Hoplocampa flava, Hoplocampa minuta) in organic farming. IOBC/WPRS Bull., 27 (5), 107-111.

Chaboussou, F. (1961). Recherches sur l'hoplocampe du pommier (Hoplocampa testudinea Klug). Méthode de lutte chimique. Ann. Epiphyt., 12, 293-315 (in French).

Ciglar, I., Barić, B. (2002). Monitoring the appearance and possibility for prevention of the apple sawfly in Croatia. J. Pest Sci., 75, 41-45.

Coli, W. M., Green, T. A., Hosmer, T. A., Prokopy, R. J. (1985). Use of visual traps for monitoring insect pests in the Massachusetts apple IPM program. Agricult. Syst. Environ., 14, 251-265.

Graf, B., Höhn, H., Höpli, H. U. (1996a). The apple sawfly, Hoplocampa testudinea: A temperature driven model for spring emergence of adults. Entomol. Experiment. Appl., 78, 301-307.

Graf, B., Höhn, H., Höpli, H. U. (1996b). Optimizing the risk assessment for the apple sawfly Hoplocampa testudinea Klug (Hymenopter, Tenthredinidae). IOBC/WPRS Bull., 19, 113-117.

Höhn, H., Höpli, H. U., Graf, B. (1993). Apfelsägewespe: Schönheitsfehler trotz Bekämpfung. Schweiz. Zeitschrift Obst. Un Weinbau, 129, 678-684 .

Lukaš, J., Kocourek, F. (1998). Monitoring of apple sawfly flight using white sticky sheets. Plant Protect. Sci., 34 (3), 98-104 (in Czech).

MacHardy, W. E. (2000). Current status of IPM in Apple orchards. Crop Protect., 19, 801-806.

Miller, F. (1956). Agricultural Entomology. Praha: SZN. 1057 pp. (in Czezh).

Nagy, B. (1959). Appearance prognosis for plum sawfly. Növényvédelem jdöszerü kérdései, 1-2, 48-57 (in Hungarian). 
Nagy, B. (1960). Fruit Sawflies (Hoplocampa spp.). Budapest: Mezőgazdasági Kiadó. 151 pp. (in Hungarian).

Raudonis, L. (ed.) (2007). Plant Protection Technologies of Horticultural Crops 2007-2008. Babtai: LSDI. 134 pp. (in Lithuanian).

Roller, L., Haris, A. (2008). Sawflies of the Carpathian Basin History and Current Research. Natura Somogyiensis. Vol. 11. Kaposvįr. 261 pp.

Taeger, A., Blank, S. M., Liston, A. D. (2006). European sawflies (Hymenoptera: Symphyta): A species checklist for the countries. In: Blank, S. M., Schmidt, S., Taeger, A. (eds.). Recent Sawfly Research: Synthesis and Prospects (pp. 399-504). Keltern: Goecke \& Evers, 704 pp.

Velbinger, H. (1939). Beitrag zur Biologie und Bekämpfung der Apfel- und Birnensägewespe (Hoplocampa testudinea KLG., Hoplocampa brevis KLG.) (Hym. Tenthr.). Gartenbauwisenschaften, 13, 492-566.

Walczak, F., Gałęzewski, M., Jakubowska, M., Rosiak, K., Tratwal, A., Złotkowski, J., Heryng, I., Gajewski, M. (2009). Harmfulness of some agrophags of cultural plants in Poland in 2008. Progr. Plant Protect., 49 (2), 508-528 (in Polish).

Wildbolz, T., Staub, A., (1984). Überwachung der Sägewespen mit Eiablagekontrollen, Befallskontrollen und weissen Fallen. Schweizerische Zeitschrift für Obst- und Weinbau 120, 228-232 (in German).

Zijp, J. P., Blommers, L. H. M., (1997). Prediction of flight of apple sawfly, Hoplocampa testudinea, using temperature sums. Entomol. Experiment. Appl., 84, 71-75.

Zijp, J. P., Blommers L. (1993). Lathrolestes ensator, a parasitoid of the apple sawfly. Proc. Sect. Exper. Appl. Entomol., 4, 237-242.

Zar, J. H. (2010). Biostatistical Analysis. 5th ed. Upper Saddle River, NJ: Pearson Education. 944 pp.

Заянчкаускас П., Йонайтис В. (1979). Перепончатокрылые Литовской CCP, их биология и экология [Hymenopterans of Lithuanian SSR, their biology and ecology]. Acta Entomol. Lituan., 4, 32-33 (in Russian)

Received 20 February 2013

ZĀG̣LAPSEN̦U (Hymenoptera, Symphyta: Hoplocampa spp.) POPULĀCIJU MONITORINGS PLŪMJU UN ĀBEḶU DĀRZOS, IZMANTOJOT VIZUĀLOS SLAZDUS

Hoplocampa minuta (Christ, 1791) (tumšā plūmju zāğlapsene), Hoplocampa flava (Linné, 1760) (plūmju zāǵlapsene) un Hoplocampa testudinea (Klug, 1816) (ābolu zāǵlapsene) populāciju izpēte tika veikta 2010. un 2011. gadā Lietuvas Lauksaimniecības un meža zinātṇu pētījumu centra Dārzkopības institūta konvencionālajā un organiskajā ābeḷu dārzā, kā arī konvencionālajā plūmju dārzā, lietojot baltas lipīgās lamatas Rebell ${ }^{\circledR}$ bianco. Tika novērotas temperatūru summas, kas nepieciešamas zāğlapseṇu pavasara invāzijas prognozēšanai: $120 \pm$ 5 grāddienas ābolu zāğlapsenei, $85 \pm 26$ melnajai plūmju zāğlapsenei un $95 \pm 28$ plūmju zāğlapsenei. Tomēr nepieciešami vairāki pētījuma gadi, lai apstiprinātu šīs temperatūru summas. Vidējais zāğlapseṇu blīvums izlidošanas laikā bija sekojošs: $H$. minuta 2010 - 14,8 $\pm 7,3$ zāğlapsenes uz slazdu ${ }^{-1}, 2011$. gadā — 54,2 $\pm 35,9$ zăğlapsenes uz slazdu ${ }^{-1}, H$. flava $2010-13,3 \pm 5,2$ zāğlapsenes uz slazdu $^{-1}$, 2011. g. —

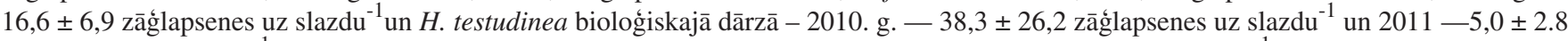

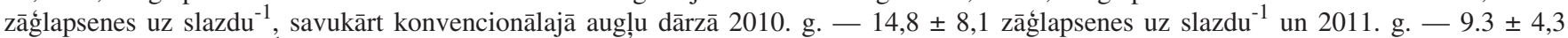
zāğglapsenes uz slazdu ${ }^{-1}$. Abām plūmju zāg̣lapseņu sugām attīstības apstākḷi bija labāki 2011. gadā un izplatība gandrīz sasniedza ekonomiskās ietekmes slieksni. Būtiskas atškirības starp pētījuma gadiem un ābeļu šķirnēm tika konstatētas ābeḷu zāğlapsenes populāciju blīvumam, kumulatīvajam slazdos nokerto kukainu skaitam izlidošanas laikā, kā arī radītajiem bojājumiem. 2010. gadā ābolu zāǵlapsene bija bieži sastopama un izraisīja vairāk nopietnu kaitējumu nekā 2011. gadā, ekonomiskais slieksnis 30-40 indivīdi katrā slazdā tika sasniegts, pateicoties labākiem attīstības apstākḷiem. Kaitējums dažādām ābeḷu šķirnes atšk̄īrās: šḳirnēm 'Aldas', 'Vitos' un 'Rubinola' augstāks kaitējums novērots organiskajā dārzā, taču būtiskas atšḳirības netika novērotas. Konvencionālajā dārzā būtiski lielāks kaitējums tika novērots škirnei 'Auksis'. 